\title{
Analisis Pengaruh Penggunaan Teknologi Informasi Terhadap Profesi Guru (Studi Kasus: Kab. Kebumen)
}

\author{
The Analysis of Information Technology Effect toward the Task of \\ Teaching Profession (Case Study: Kebumen Regency)
}

\author{
Sapto Wimartono ${ }^{1}$, Bambang Soedijono W. A. ${ }^{2}$, Armadyah Amborowati ${ }^{3}$ \\ ${ }^{1,2}$ Magister Teknik Informatika STMIK AMIKOM Yogyakarta \\ ${ }^{3}$ Teknik Informatika STMIK AMIKOM Yogyakarta \\ E-mail: *11 saptowimartono@gmail.com, ${ }^{2}$ bambang.s@ amikom.ac.id, \\ 3armadyah.a@amikom.ac.id
}

\begin{abstract}
Abstrak
Penelitian ini bertujuan untuk mengetahui pengaruh penggunaan teknologi informasi terhadap profesi guru di Kabupaten Kebumen. Penelitian melibatkan 100 responden guru SMP negeri maupun swasta sebagai sampel. Jumlah guru SMP/MTs menurut data dari Badan Pusat Statistik Kabupaten Kebumen adalah sebanyak 4.464 orang.

Hasil analisis data dengan regresi linier menunjukkan faktor - faktor seorang guru menggunakan teknologi informasi dipengaruhi oleh faktor sosial dengan koefisien sebesar 46,0\%, kesesuaian tugas sebesar 30\%, kondisi yang memfasilitasi sebesar -10,1\% (berkontribusi negatif), Kompleksitas sebesar -48,0\% (berkontribusi negatif), Konsekuensi jangka panjang sebesar 14,0\%, dan faktor Affect (perasaan individu) sebesar 20,4\%. Keberadaan teknologi informasi berkontribusi negatif, artinya kehadirannya belum mendapat respon yang positif oleh guru.

Penelitian ini merekomendasikan perlunya peningkatan kompetensi TIK bagi guru melalui pelatihan TIK. Merujuk pada tugas guru dalam menjalankan kompetensi pedagogik dan profesional, maka pelatihan yang diusulkan meliputi pembuatan presentasi materi ajar dan publikasi materi ajar secara online.
\end{abstract}

Kata Kunci — Teknologi Informasi, Regresi Linier, Kompleksitas, Pelatihan TIK

\section{Abstract}

This research aims to find out the effect of using information technology toward the teaching profession in Kebumen regency. The research involves 100 respondents of state and private Junior High School teachers as samples. The number of SMP/MTs teachers according to data from Central Bureau of Statistic in Kebumen regency is 4.464 people.

The result of data analysis with linear regression indicates the factor of a teacher using information technology are influenced by the social factor with coefficient 46\%, the task compatibility $30,0 \%$, the facilitating condition $-10,1 \%$ (contributing negative) the complexity $48,0 \%$ (contributing negative), the long term consequences $14,0 \%$ and the affect factor (individual feeling) 20,4\%. The existence of information technology contributes negative. It means the presence of it has not got positive response from teacher.

This research recommends that it is necessary to increase the competence of ICT for teacher by training. Referring to the task of teacher in doing profesional and pedagogy competence, then the proposed trainings involve presentation of making teaching materials and teaching materials online publication.

Keywords — information technology, linear regression, complexity, ICT training 


\section{PENDAHULUAN}

Berbicara tentang masalah pendidikan, berarti membahas perkembangan peradaban manusia. Perkembangan pendidikan manusia akan berpengaruh terhadap dinamika sosial - budaya masyarakatnya. Pendidikan akan terus mengalami perkembangan sesuai dengan perkembangan kebudayaan..

Guru sebagai ujung tombak pendidikan, yang bersentuhan langsung dengan peserta didik akan menentukan seberapa besar tingkat kemampuan peserta didik dalam menerima ilmu yang diberikan oleh guru tersebut. Sebuah kenyataan bahwa metode pembelajaran yang dilakukan oleh seorang guru terkadang terkesan monoton dan membosankan. Buku pelajaran, papan tulis dan kapur masih mendominasi dalam setiap aktifitas belajar mengajar.

Dalam UU RI No. 20 Tahun 2003 tentang Sistem Pendidikan Nasional, pasal 1. dijelaskan bahwa : "Pendidikan adalah usaha sadar dan terencana untuk mewujudkan suasana belajar dan proses pembelajaran agar peserta didik secara aktif mengembangkan potensi dirinya untuk memiliki kekuatan spiritual keagamaan, pengendalian diri, kepribadian, kecerdasan, akhlak mulia, serta keterampilan yang diperlukan dirinya, masyarakat, bangsa dan negara. ${ }^{[1]}$

Dalam Peraturan Menteri Pendidikan Nasional no. 41 Tahun 2007 tentang Standar Proses, pasal 1 menjelaskan bahwa Standar Proses untuk satuan pendidikan dasar dan menengah mencakup perencanaan proses pembelajaran, pelaksanaan proses pembelajaran, penilaian hasil pembelajaran, dan pengawasan proses pembelajaran yang efektif dan efisien. ${ }^{[2]}$

Untuk mendukung kinerja guru dalam melaksanakan peran dan tugasnya di sekolah khususnya dalam proses pembelajaran dalam konteks sekarang ini memerlukan pengembangan dan perubahan ke arah yang lebih inovatif, kinerja inovatif guru menjadi hal yang penting bagi berhasilnya implementasi inovasi pendidikan dalam rangka meningkatkan kualitas pendidikan atau pembelajaran. Informasi dan sistem teknologi komunikasi sangat menunjang keberhasilan dalam melaksanakan pekerjaan (Teece, 1997; Korpelainen et al., 2010). ${ }^{[3]}$

Manfaat komputer untuk tujuan pendidikan menurut Arsyad (dalam Rusman, dkk., 2011:47) yaitu:

1. Komputer dapat mengakomodasi siswa yang lamban menerima pelajaran karena ia dapat memberikan iklim yang lebih bersifat afektif dengan cara yang lebih individual, tidak pernah lupa, tidak pernah bosan, sangat sabar dalam menjalankan instruksi seperti yang diinginkan program yang digunakan.

2. Komputer dapat merangsang siswa untuk mengerjakan latihan, melakukankegiatan laboratorium atau simulasi karena tersedianya animasi grafik, warna,dan musik yang dapat menambah realisme.

3. Kendali berada di tangan siswa, sehingga tingkat kecepatan belajar siswa dapat disesuaikan dengan tingkat penguasaannya. Dengan kata lain, komputer dapat berinteraksi dengan siswa secara individual.

4. Kemampuan merekam aktivitas siswa selama menggunakan program pembelajaran, memberikan kesempatan lebih baik untuk pembelajaran secara perorangan dan perkembangan setiap siswa selalu dapat dipantau.

5. Dapat berhubungan dengan, dan mengendalikan peralatan lain seperti CD interaktif, video, dan lain-lain dengan program pengendali dari komputer. ${ }^{[4]}$

Dalam penelitian yang dilakukan oleh Asye Rachmawaty (2014), bertujuan untuk mengetahui dan menganalisa pengaruh pemanfaatan teknologi informasi terhadap kinerja guru Sekolah Menengah Pertama Negeri 43 Bandung, baik secara simultan maupun secara parsial. Hasil penelitian menyimpulkan bahwa pemanfaatan teknologi informasi pada SMPN 43 Bandung secara simultan dan parsial mempunyai pengaruh terhadap kinerja guru. Penelitian menggunakan tiga variabel yaitu meliputi sikap terhadap penggunaan system, persepsi kegunaan system dan kinerja guru, penelitian dilakukan dengan metode $\mathrm{TAM}^{[5]}$. 
Pada penelitian yang akan dilakukan menganalisis pengaruh penggunaan teknologi informasi terhadap profesi guru di Kabupaten Kebumen, menggunakan enam variabel bebas dengan model MPCU. ${ }^{[6]}$

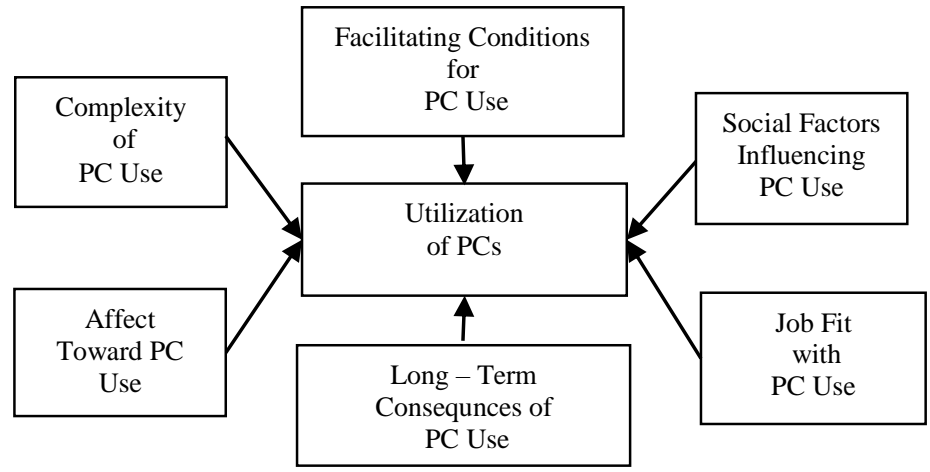

Gambar 1. Model of PC Utilization

\section{METODE PENELITIAN}

Metode penelitian yang digunakan untuk menjawab penelitian ini adalah metode penelitian asosiatif korelasional dengan pendekatan kuantitatif. Pengujian hipotesis pada penelitian asosiatif korelasional dengan pendekatan kuantitatif, dilakukan untuk menjawab tiga pertanyaan penelitian tentang dua variabel atau lebih (Sudayana, R, 2014: 192) ${ }^{[7]}$. Pertanyaan tersebut yaitu:

1. Adakah hubungan diantara dua variabel?

2. Bagaimana arah hubungan tersebut?

3. Berapa besar/ jauh hubungan tersebut dapat diterangkan?

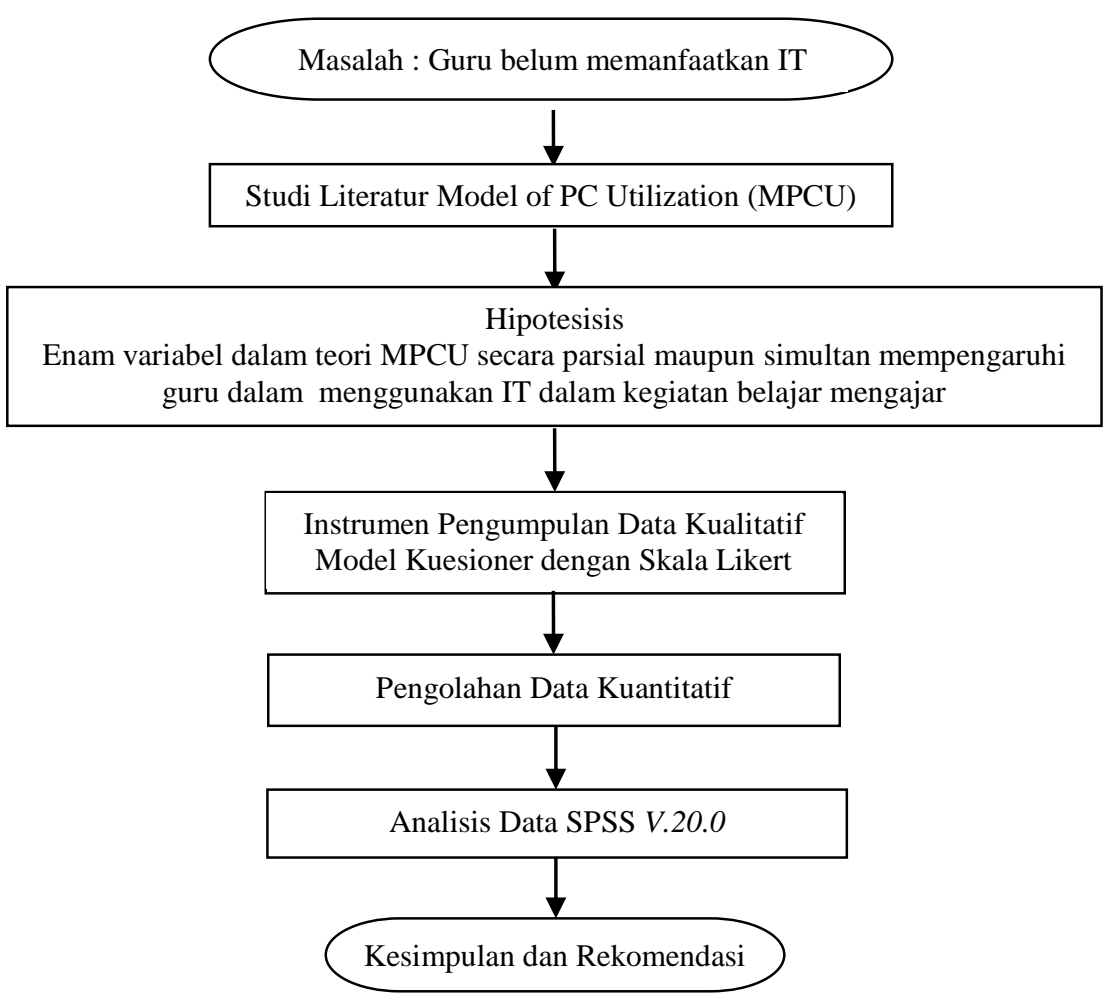

Gambar 2. Alur Penelitian Asosiatif Korelasional yang dilakukan 


\subsection{Metode Pengumpulan Data}

Pengumpulan data dilakukan dengan studi literatur dan mengambil langsung dari sumbernya (populasi) yaitu dengan teknik sampling dengan instrumen berupa kuesioner. Pada kuesioner, setiap item kuesioner dikuantitatifkan dengan menggunakan skala Likert.

\subsubsection{Populasi}

Populasi adalah jumlah keseluruhan dari unit analisa yang cirinya diduga. Atau dengan kata lain populasi didefinisikan sebagai keseluruhan subyek atau obyek yang menjadi sasaran penelitian yang mempunyai karakteristik tertentu.

\subsubsection{Sampel}

Menurut Singarimbun (1989:53), sampel diartikan sebagian dari populasi yang menjadi sumber data yang sebenarnya dengan kata lain, sampel adalah sebagian dari populasi. Salah satu metode yang digunakan untuk menentukan jumlah sampel adalah menggunakan rumus Slovin (Sevilla et. al., 1960:182), dalam persamaan $(1)^{[8]}$

$$
n=\frac{\mathrm{N}}{1+\mathrm{N} e^{2}}
$$

$$
\begin{aligned}
& n=\text { ukuran sampel } \\
& \mathrm{N}=\text { ukuran populasi } \\
& e=\text { toleransi ketidaktelitian (dalam penelitian ini diambil } e=0,1 \text { ) }
\end{aligned}
$$

Pengambilan sampel dilakukan dengan teknik sampling random sederhana. Sampling random sederhana digunakan jika populasi bersifat homogen Pengambilan sampel random sederhana dilakukan dengan mengambil sampel secara acak tanpa memandang strata yang ada dalam populasi tersebut.

\subsection{Metode Analisis Data}

\subsubsection{Analisis Regresi Linier Berganda}

Analisis Regresi Linier Berganda (Multiple Linear Regression) digunakan untuk mengetahui seberapa besar pengaruh variabel - variabel independen terhadap variabel dependen. Analisis ini didasarkan pada hubungan satu variabel dependen dengan satu atau lebih variabel independen. Analisis ini digunakan untuk mengetahui hubungan antara dua atau lebih variabel independen $\left(\mathrm{X}_{1}, \mathrm{X}_{2}, \ldots \mathrm{X}_{\mathrm{n}}\right)$ terhadap variabel dependen $(\mathrm{Y})$ secara serentak. Koefisien pada setiap variabel independen menunjukkan seberapa besar variabel tersebut mempengaruhi variabel dependen $(\mathrm{Y})$.

Data yang digunakan untuk variabel dependen adalah kuantitatif, jika menggunakan variabel kategori maka perlu diubah ke bentuk numerik dengan memberi value. Asumsi yang mendasari pada analisis regresi linier adalah bahwa distribusi data adalah normal dan hubungan antara variabel dependen dengan masing-masing variabel independen adalah linier. Selain itu terdapat asumsi klasik yang biasanya digunakan yaitu tidak adanya multikolinearitas, heteroskedastisitas dan autokorelasi pada model regresi.

Persamaan regresi linier berganda adalah ditulis dalam bentuk persamaan (2)

$$
\mathrm{Y}^{\prime}=\mathrm{b}_{0}+\mathrm{b}_{1} \mathrm{X}_{1}+\mathrm{b}_{2} \mathrm{X}_{2+\ldots \ldots+} \mathrm{nX_{ \textrm {m } }}
$$

$\mathrm{Y}^{\prime}$ adalah variabel dependen yang dipengaruhi, $\mathrm{b}_{0}, \mathrm{~b}_{1}, \mathrm{~b}_{2}$, adalah koefisien regresi, $\mathrm{X}_{1}$ dan $\mathrm{X}_{2}$, adalah variabel independen. Secara jelas gambaran tentang analisis regresi linier berganda ditunjukkan dalam sebuah alur kerangka berpikir dimana variabel independen dapat 
mempengaruhi variabel dependen secara sendiri - sendiri (parsial) maupun secara serentak (simultan) semua variabel independen mempengaruhi variabel dependen.

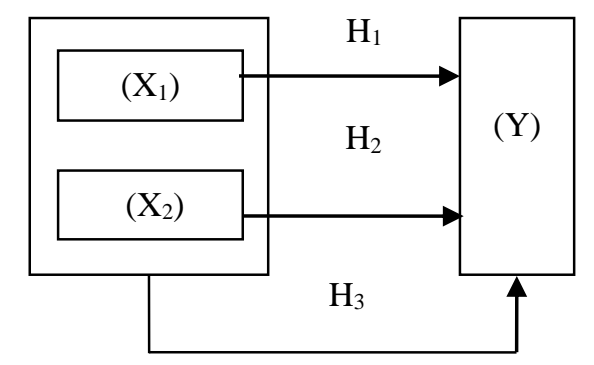

Gambar 3. Kerangka Pemikiran Analisis Regresi Linier Berganda dengan 2 variabel bebas $\mathrm{X}_{1}$ dan $\mathrm{X}_{2}$

$\mathrm{H}_{1}, \mathrm{H}_{2}$ adalah hipotesis adanya pengaruh signifikan setiap variabel independen $\mathrm{X}_{1}$, dan $\mathrm{X}_{2}$ secara parsial. $\mathrm{H}_{3}$ adalah hipotesis adanya pengaruh signifikan variabel independen $\mathrm{X}_{1}, \mathrm{X}_{2}$ secara serentak (simultan) terhadap variabel dependen (Y).

Metode analisis data dilakukan dengan menggunakan software SPSS Ver. 20.0. Analisis regresi linear berganda meliputi, Uji regresi serentak/simultan (Uji F). Uji pengaruh variabel secara parsial (Uji t), Analisis Koefisien Determinasi $\left(\mathrm{R}^{2}\right)$, Uji Normalitas, Uji Multikolineritas dan Uji Heteroskedastisitas. ${ }^{[9]}$

\section{HASIL DAN PEMBAHASAN}

\subsection{Profil Kabupaten Kebumen}

Kabupaten Kebumen terletak antara $7^{\circ} 27^{\prime}-7^{\circ} 50^{\prime}$ LS dan $109^{\circ} 22^{\prime}$ - $109^{\circ} 50^{\prime}$ BT. Sebelah utara berbatasan dengan Kabupaten Wonosobo dan Kabupaten Banjarnegara, sebelah timur berbatasan dengan Kabupaten Purworejo, sebelah selatan berbatasan dengan Samudra Indonesia dan sebelah barat berbatasan dengan Kabupaten Banyumas dan Kabupaten Cilacap. Luas wilayah Kabupaten Kebumen adalah 128.111,50 Ha atau 1.281,115 km². Menurut data pada Badan Pusat Statistik Kabupaten Kebumen, kabupaten ini mempunyai SD sebanyak 907 buah, SMP/MTs sebanyak 198 buah, SMA/MA/SMK sebanyak 110 buah. Jumlah keseluruhan guru 16.204 orang. Jumlah keseluruhan murid 250.872 anak.

\subsection{Hipotesa Penelitian yang Diusulkan}

Hipotesis yang diajukan dalam penelitian ini terdiri dari enam variabel bebas/independent yang mempengaruhi variabel terikat/dependent seperti dalam tabel 1 .

Tabel 1. Variabel bebas dan terikat

\begin{tabular}{|c|c|}
\hline Variabel bebas / independent $(\mathrm{X})$ & Variabel terikat /dependent (Y) \\
\hline X1 : Faktor sosial & \multirow{6}{*}{ Penggunaan IT dalam tugas profesi guru } \\
\hline $\mathrm{X} 2:$ Kesesuaian tugas & \\
\hline $\mathrm{X} 3$ : Kondisi yang memfasilitasi & \\
\hline $\mathrm{X} 4:$ Kompleksitas & \\
\hline X5 : Konsekuensi jangka panjang & \\
\hline X6 : Affect toward (perasaan individu) & \\
\hline
\end{tabular}


Citec Journal, Vol. 3, No. 1, November 2015 - Januari 2016

Relasi antar variabel bebas (X) terhadap variabel terikat (Y) adalah seperti dalam tabel 2.

Tabel 2. Hipotesis penelitian yang diusulkan

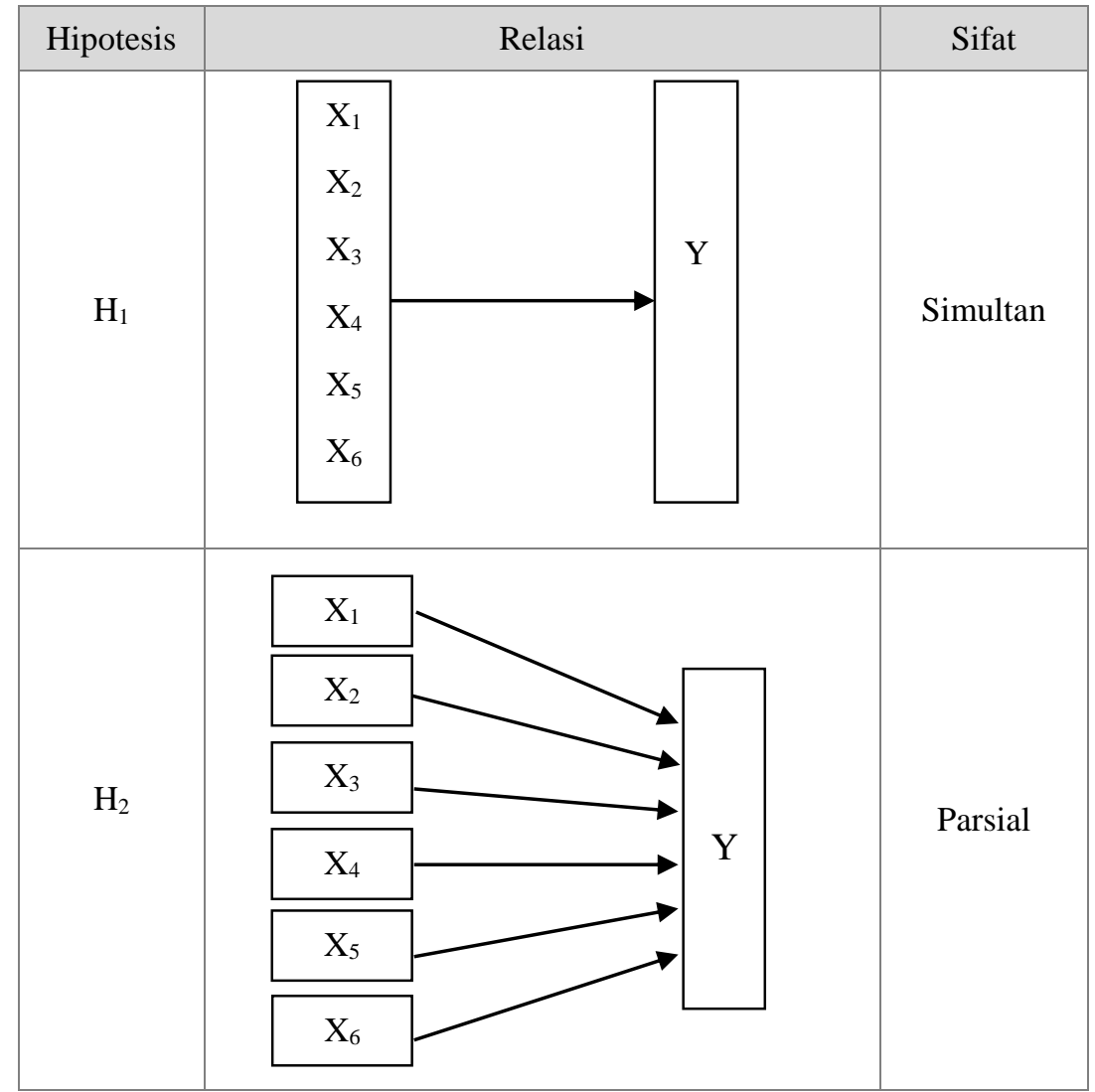

\subsection{Penentuan Jumlah Sampel}

Jumlah guru SMP dan MTs yang berstatus PNS dan Non PNS di Kabupaten Kebumen menurut Badan Pusat Statistik Kabupaten Kebumen adalah 4.464 orang. Dengan menggunakan rumus Slovin diperoleh hitungan sebagai berikut:

$$
\begin{aligned}
& n=\frac{4464}{1+4464(0,1)^{2}} \\
& n=\frac{4464}{1+4464(0,01)} \\
& n=97,8 \approx 100 \text { orang }
\end{aligned}
$$

Terhadap 100 responden diberikan kuesioner yang merepresentasikan variabel - variabel yang akan diteliti. 


\subsection{Analisis Data Hasil Penelitian}

\subsubsection{Uji Validitas dan Reliabilitas Data}

Hasil uji validitas kuesioner dengan 100 responden, $r_{\text {tabel }}$ untuk responden $(\mathrm{N})=100$ adalah 0,195. Apabila $r_{\text {hitung }}>r_{\text {tabel }}$ maka item kuesioner dinyatakan valid. Hasil $r_{\text {hitung }}$ uji validitas tampak dalam tabel 3.

Tabel 3. Uji Validitas

\begin{tabular}{|c|c|c|}
\hline \multicolumn{2}{|r|}{ Variabel } & $\begin{array}{l}\text { Corrected Item- } \\
\text { Total Correlation }\end{array}$ \\
\hline \multirow{3}{*}{$\mathrm{X}_{1}$} & Sosial1(X1) & ,446 \\
\hline & Sosial2(X1) & ,462 \\
\hline & Sosial3(X1) & ,456 \\
\hline \multirow{5}{*}{$\mathrm{X}_{2}$} & Kesesuaian Tugas1(X2) & ,709 \\
\hline & Kesesuaian Tugas2(X2) & 640 \\
\hline & Kesesuaian Tugas3(X2) & ,491 \\
\hline & Kesesuaian Tugas4(X2) & ,391 \\
\hline & Kesesuaian Tugas5(X2) &, 587 \\
\hline \multirow{3}{*}{$\mathrm{X}_{3}$} & Kondisi Yang Memfasilitasi1(X3) &, 535 \\
\hline & Kondisi Yang Memfasilitasi2(X3) & ,212 \\
\hline & Kondisi Yang Memfasilitasi3(X3) & ,326 \\
\hline \multirow{11}{*}{$\mathrm{X}_{4}$} & Kompleksitas1(X4) & ,725 \\
\hline & Kompleksitas2(X4) & ,685 \\
\hline & Kompleksitas3(X4) & ,767 \\
\hline & Kompleksitas4(X4) & ,476 \\
\hline & Kompleksitas5(X4) & ,813 \\
\hline & Kompleksitas6(X4) & ,834 \\
\hline & Kompleksitas7(X4) & ,779 \\
\hline & Kompleksitas8(X4) & ,793 \\
\hline & Komplkesitas9(X4) & 630 \\
\hline & Kompleksitas10(X4) & ,657 \\
\hline & Kompleksitas11(X4) & 625 \\
\hline \multirow{4}{*}{$\mathrm{X}_{5}$} & Konsekuensi Jangka Panjang1(X5) & ,457 \\
\hline & Konsekuensi Jangka Panjang2(X5) & ,788 \\
\hline & Konsekuensi Jangka Panjang3(X5) & ,725 \\
\hline & Konsekuensi Jangka Panjang4(X5) & ,636 \\
\hline \multirow{3}{*}{$\mathrm{X}_{6}$} & Affect (Perasaan Individu)1(X6) & ,745 \\
\hline & Affect (Perasaan Individu)2(X6) & ,730 \\
\hline & Affect (Perasaan Individu)3(X6) & ,708 \\
\hline \multirow{7}{*}{$\mathrm{Y}$} & Penggunaan IT dalam tugas profesi guru1(Y) & ,648 \\
\hline & Penggunaan IT dalam tugas profesi guru2(Y) & ,872 \\
\hline & Penggunaan IT dalam tugas profesi guru3(Y) & ,885 \\
\hline & Penggunaan IT dalam tugas profesi guru4(Y) & ,853 \\
\hline & Penggunaan IT dalam tugas profesi guru5(Y) & 800 \\
\hline & Penggunaan IT dalam tugas profesi guru6(Y) & ,810 \\
\hline & Penggunaan IT dalam tugas profesi guru7(Y) & ,771 \\
\hline
\end{tabular}

Hasil hitung terhadap kuesioner menujukkan $r_{\text {hitung }}>r_{\text {tabel }} 0,195$ 
Citec Journal, Vol. 3, No. 1, November 2015 - Januari 2016

Hasil uji reliabilitas kuesioner dengan 100 responden, $r_{\text {tabel }}$ untuk responden $(\mathrm{N})=100$ adalah 0,195. Apabila alpa cronbach $>r_{\text {tabel }}$ maka item kuesioner dinyatakan reliabel. Hasil alpha cronbach tampak dalam tabel 4.

Tabel 4. Alpha Cronbach

\begin{tabular}{|r|r|r|}
\hline $\begin{array}{c}\text { Cronbach's } \\
\text { Alpha }\end{array}$ & N of Items & \multicolumn{1}{c|}{ Variabel } \\
\hline, 638 & 3 & $\mathrm{X}_{1}$ \\
\hline, 778 & 5 & $\mathrm{X}_{2}$ \\
\hline, 536 & 3 & $\mathrm{X}_{3}$ \\
\hline, 927 & 11 & $\mathrm{X}_{4}$ \\
\hline, 823 & 4 & $\mathrm{X}_{5}$ \\
\hline, 848 & 3 & $\mathrm{X}_{6}$ \\
\hline, 940 & 7 & $\mathrm{Y}$ \\
\hline
\end{tabular}

Hasil hitung terhadap kuesioner menujukkan alpa cronbach $>r_{\text {tabel }} 0,195$

\subsubsection{Analisis Regresi Linier Berganda}

Hasil analisis regresi linier berganda dengan aplikasi SPSS ver. 20 diperoleh data seperti dalam tabel 5.

Tabel 5. Analisis regresi linier berganda

$$
\text { Coefficients }^{\mathrm{a}}
$$

\begin{tabular}{|c|c|c|c|c|c|c|c|c|}
\hline & \multirow{2}{*}{ Model } & \multicolumn{2}{|c|}{$\begin{array}{l}\text { Unstandardized } \\
\text { Coefficients }\end{array}$} & \multirow{2}{*}{$\begin{array}{c}\text { Standardized } \\
\text { Coefficients } \\
\text { Beta }\end{array}$} & \multirow[b]{2}{*}{$\mathrm{t}$} & \multirow[t]{2}{*}{ Sig. } & \multicolumn{2}{|c|}{$\begin{array}{l}\text { Collinearity } \\
\text { Statistics }\end{array}$} \\
\hline & & B & $\begin{array}{l}\text { Std. } \\
\text { Error }\end{array}$ & & & & $\begin{array}{c}\text { Toleran } \\
\text { ce }\end{array}$ & VIF \\
\hline \multirow{7}{*}{1} & (Constant) & 2,888 & ,588 & & 4,909 &, 000 & & \\
\hline & Sosial(x1) &, 046 & 052 &, 056 & ,895 & ,373 & ,913 & 1,095 \\
\hline & Kesesuaian tugas(X2) & ,300 & ,065 & ,352 & 4,628 &, 000 & ,614 & 1,628 \\
\hline & Kondisi yang memfasilitasi(X3) &,- 101 & 100 &,- 076 & $-1,008$ & ,316 & ,622 & 1,608 \\
\hline & Kompleksitas(X4) &,- 480 & 074 &,- 494 & $-6,495$ &, 000 & ,614 & 1,628 \\
\hline & Konsekuensi jangka panjang(X5) &, 014 &, 117 & 010 &, 117 & ,907 &, 524 & 1,907 \\
\hline & Affect toward(X6) & ,204 & ,093 &, 172 & 2,194 &, 031 &, 580 & 1,723 \\
\hline
\end{tabular}

a. Dependent Variable: Penggunaan IT dalam tugas profesi guru

Berdasarkan tabel Coefficient, persamaan regresi linier berganda yang diperoleh adalah sebagai berikut:

$$
Y=2,888+0,046 X_{1}+0,300 X_{2}-0,101 X_{3}-0,480 X_{4}+0,014 X_{5}+0,204 X_{6}
$$

Persamaan regresi tersebut dapat dijelaskan sebagai berikut:

1. Berdasarkan data yang diperoleh dari responden, perolehan rata - rata skor untuk masingmasing variabel seperti pada tabel 6 .

Tabel 6. Perolehan rata- rata skor kuesioner

\begin{tabular}{|c|c|c|c|c|c|c|}
\hline \multicolumn{6}{|c|}{ Rata - rata skor kuesioner responden dengan rentang skor 1 - 5 } \\
\hline $\mathrm{X}_{1}$ & $\mathrm{X}_{2}$ & $\mathrm{X}_{3}$ & $\mathrm{X}_{4}$ & $\mathrm{X}_{5}$ & $\mathrm{X}_{6}$ & $\mathrm{Y}$ \\
\hline 3,49 & 3,33 & 4,14 & 2,79 & 4,42 & 4,29 & 3,23 \\
\hline
\end{tabular}


Interpretasi pada variabel Y adalah:

\begin{tabular}{|l|l|}
\hline Skor & Interpretasi \\
\hline 1 & Tidak pernah menggunakan IT \\
\hline 2 & Jarang menggunakan IT \\
\hline 3 & Kadang menggunakan IT \\
\hline 4 & Sering menggunakan IT \\
\hline 5 & Selalu menggunakan IT \\
\hline
\end{tabular}

Interpretasi skala untuk Penggunaan IT dengan skor minimal 1dan maksimal 5 adalah:

\begin{tabular}{|c|c|c|c|c|}
\hline 1,0 s.d. $<1,8$ & 1,8 s.d. $<2,6$ & 2,6 s.d. $<3,4$ & 3,4 s.d. $<4,2$ & 4,2 s.d. 5,0 \\
\hline Tidak Pernah & Jarang & Kadang & Sering & Selalu \\
\hline
\end{tabular}

Hasil penelitian menunjukkan perolehan skor rata - rata untuk penggunaan IT pada saat penelitian dilakukan adalah 3,23. Artinya penggunaan IT oleh guru untuk mendukung tugas profesinya masih berada pada interpretasi Kadang menggunakan IT.

2. Koefisien faktor Sosial $\left(\mathrm{X}_{1}\right)$ sebesar 0,046 artinya jika variabel independen yang lain tetap sedangkan faktor Sosial $\left(\mathrm{X}_{1}\right)$ dinaikkan senilai 1 satuan dari 3,49 menjadi 4,49 maka nilai $\mathrm{Y}$ (penggunaan IT oleh guru) akan meningkat dari 3,23 menjadi 3,27 atau 1,24\%.

3. Koefisien faktor Kesesuaian Tugas $\left(\mathrm{X}_{2}\right)$ sebesar 0,3 artinya jika variabel tersebut mengalami kenikan senilai 1 satuan dari 3,33 menjadi 4,33, sedangkan variabel independen yang lain tetap, maka terjadi peningkatan penggunaan IT dari 3,23 menjadi 3,53 atau 9,28\%.

4. Koefisien Kondisi yang memfasilitasi $\left(\mathrm{X}_{3}\right)$ sebesar $(-0,101)$ artinya jika variabel tersebut mengalami kenaikan seniali 1satuan dari 4,14 menjadi 5,14 sedangkan variabel yang lain tetap, maka akan terjadi penurunan penggunaan IT dari 3,23 menjadi 3,13 atau menurun $3,09 \%$. Hal ini menunjukkan bahwa penambahan fasilitas IT tidak secara otomatis meningkatkan penggunaan IT.

5. Koefisien Kompleksitas $\left(\mathrm{X}_{4}\right)$ sebesar $(-0,480)$ artinya jika variabel tersebut mengalami kenaikan 1satuan dari 2,79 menjadi 3,79 sedangkan variabel yang lain tetap, maka akan mengakibatkan penurunan penggunaan IT bagi guru dari 3,23 menjadi 2,74 atau menurun $14,86 \%$. Sebaliknya jika variabel Kompleksitas $\left(\mathrm{X}_{4}\right)$ diturunkan 1 satuan maka akan terjadi peningkatan dari 3,23 menjadi 3,71 atau meningkat 14,86\%. Artinya disini perlu dilakukan upaya menurunkan variabel Kompleksitas agar Penggunaan IT mengalami kenaikan. Penurunan Kompleksitas dapat dilakukan dengan mengadakan pelatihan - pelatihan IT.

6. Koefisien Konsekuensi Jangka Panjang $\left(\mathrm{X}_{5}\right)$ sebesar 0,140 artinya jika variabel tersebut mengalami kenaikan 1satuan dari 4,42 menjadi 5,42 sedangkan variabel independen yang lain tetap, maka terjadi peningkatan penggunaan IT 3,23 menjadi 3,24 atau 0,31\%.

7. Koefisien Affect toward (Perasaan Individu) $\left(\mathrm{X}_{6}\right)$ sebesar 0,204 artinya jika variabel tersebut mengalami kenaikan 1satuan dari 4,29 menjadi 5,29 sedangkan variabel independen yang lain tetap, maka terjadi peningkatan penggunaan IT dari 3,23 menjadi 3,43 atau 6,19\%. 


\subsubsection{Uji Simultan (Uji F)}

Digunakan untuk mengetahui pengaruh secara serentak variabel independen terhadap variabel independen seperti tampak dalam tabel 7.

Tabel 7. Uji Simultan

ANOVA $^{\mathrm{a}}$

\begin{tabular}{|c|l|r|r|r|c|c|}
\hline \multicolumn{2}{|c|}{ Model } & Sum of Squares & df & Mean Square & F & Sig. \\
\hline \multirow{3}{*}{1} & Regression & 30,374 & 6 & 5,062 & 31,377 &, $000^{\mathrm{b}}$ \\
& Residual & 15,005 & 93 &, 161 & & \\
& Total & 45,379 & 99 & & & \\
\hline
\end{tabular}

a. Dependent Variable: Penggunaan IT dalam tugas profesi guru

b. Predictors: (Constant), Affect toward(X6), Sosial(x1), Kesesuaian tugas(X2), Kondisi yang memfasilitasi(X3), Kompleksitas(X4), Konsekuensi jangka panjang(X5)

a. Tabel $F_{\text {kritis }}$ untuk taraf signifikansi $0,05 \mathrm{df} 1=\mathrm{k}-1$ atau $7-1=6$, dan df $2=\mathrm{n}-\mathrm{k}$ atau 100 $-7=93$ adalah sebesar $\mathbf{2 , 1 9 8}$.

b. $F_{\text {hitung }}$ pada tabel ANOVA adalah $\mathbf{3 1 , 3 7 7}$

c. Kesimpulan karena $F_{\text {hitung }}(31,377)>F_{\text {kritis }}(2,198)$ maka variabel Sosial $\left(\mathrm{X}_{1}\right)$, Kesesuaian tugas $\left(\mathrm{X}_{2}\right)$, Kondisi yang memfasilitasi $\left(\mathrm{X}_{3}\right)$, Kompleksitas $\left(\mathrm{X}_{4}\right)$, Konsekuensi jangka panjang $\left(\mathrm{X}_{5}\right)$ dan Affect toward (perasaan individu) $\left(\mathrm{X}_{6}\right)$ secara serentak berpengaruh terhadap variabel Penggunaan IT dalam tugas profesi guru (Y).

Dalam penelitian ini, variabel Sosial $\left(\mathrm{X}_{1}\right)$, Kesesuaian tugas $\left(\mathrm{X}_{2}\right)$, Konsekuensi jangka panjang $\left(\mathrm{X}_{5}\right)$ dan Affect toward (perasaan individu) $\left(\mathrm{X}_{6}\right)$ berpengaruh positif, sedangkan variabel kondisi yang memfasilitasi $\left(\mathrm{X}_{3}\right)$ dan kompleksitas $\left(\mathrm{X}_{4}\right)$ berpengaruh negatif.

\subsubsection{Uji Parsial (Uji t)}

Digunakan untuk mengetahui pengaruh setiap variabel independen terhadap variabel dependen secara parsial seperti tampak pada tabel 8 .

Tabel 8. Uji Parsial

\begin{tabular}{|c|c|c|c|c|c|c|c|c|}
\hline \multicolumn{9}{|c|}{ Coefficients $^{\mathrm{a}}$} \\
\hline & \multirow[t]{2}{*}{ Model } & \multicolumn{2}{|c|}{$\begin{array}{l}\text { Unstandardized } \\
\text { Coefficients }\end{array}$} & \multirow{2}{*}{$\begin{array}{c}\text { Standardized } \\
\text { Coefficients } \\
\text { Beta }\end{array}$} & \multirow{2}{*}{$\mathrm{t}$} & \multirow{2}{*}{ Sig. } & \multicolumn{2}{|c|}{$\begin{array}{l}\text { Collinearity } \\
\text { Statistics }\end{array}$} \\
\hline & & B & $\begin{array}{l}\text { Std. } \\
\text { Error }\end{array}$ & & & & Tolerance & VIF \\
\hline \multirow{7}{*}{1} & (Constant) & 2,888 &, 588 & & 4,909 &, 000 & & \\
\hline & Sosial(x1) &, 046 &, 052 &, 056 &, 895 &, 373 & ,913 & 1,095 \\
\hline & Kesesuaian tugas(X2) &, 300 &, 065 & ,352 & 4,628 &, 000 & ,614 & 1,628 \\
\hline & $\begin{array}{l}\text { Kondisi yang } \\
\text { memfasilitasi(X3) }\end{array}$ &,- 101 &, 100 &,- 076 & $-1,008$ &, 316 & ,622 & 1,608 \\
\hline & Kompleksitas(X4) &,- 480 &, 074 &,- 494 & $-6,495$ &, 000 & ,614 & 1,628 \\
\hline & $\begin{array}{l}\text { Konsekuensi jangka } \\
\text { panjang(X5) }\end{array}$ &, 014 &, 117 &, 010 &, 117 & ,907 &, 524 & 1,907 \\
\hline & Affect toward(X6) & ,204 & ,093 &, 172 & 2,194 & ,031 &, 580 & 1,723 \\
\hline
\end{tabular}

a. Dependent Variable: Penggunaan IT dalam tugas profesi guru

a. Tabel $\boldsymbol{t}_{\text {kritis }}$ pada taraf signifikansi $0,05 / 2=0,025$ (uji dua sisi) dengan $\mathrm{df}=\mathrm{n}-\mathrm{k}-1$ atau $100-6-1=93$ (k adalah jumlah variabel independen) adalah $\mathbf{1 , 9 8 6}$. 
b. Pengambilan keputusan:

- Jika $t_{\text {hitung }} \leq t_{\text {kritis }}$, atau Sig $>$ dari 0,05 (0,05 adalah taraf signifikan yang digunakan) maka kesimpulannya tidak berpengaruh signifikan

- Jika $t_{\text {hitung }}>t_{\text {kritis, }}$, atau Sig < dari 0,05 (0,05 adalah taraf signifikan yang digunakan) maka kesimpulannya berpengaruh signifikan

c. Kesimpulan berdasarkan perbandingan $\boldsymbol{t}_{\text {hitung }}$ dengan $\boldsymbol{t}_{\text {krits }}$ adalah sebagai berikut:

- Sosial $\left(\mathrm{X}_{1}\right): \mathrm{t}_{\text {hitung }} 0,895<t_{\text {kritis }} 1,986$

Kesimpulan: faktor sosial tidak menjadi faktor yang berpengaruh signifikan.

- Kesesuaian tugas $\left(\mathrm{X}_{2}\right): t_{\text {hitung }} 4,6285>t_{\text {kritis }} 1,986$

Kesimpulan: faktor kesesuaian tugas menjadi faktor yang berpengaruh signifikan.

- Kondisi yang memfasilitasi $\left(\mathrm{X}_{3}\right): t_{\text {hitung }}-1,008<t_{\text {kritis }} 1,986$

Kesimpulan: faktor kondisi yang memfasilitasi tidak menjadi faktor yang berpengaruh signifikan. (nilai $t$ negatif menunjukkan bahwa $\mathrm{X}_{2}$ mempunyai hubungan yang berlawanan arah dengan $\mathrm{Y}$ )

- Kompleksitas $\left(\mathrm{X}_{4}\right): t_{\text {hitung }}-6,495>t_{\text {kritis }} 1,986$

Kesimpulan: faktor kompleksitas menjadi faktor yang berpengaruh signifikan (nilai $t$ negatif menunjukkan bahwa $\mathrm{X}_{4}$ mempunyai hubungan yang berlawanan arah dengan $\mathrm{Y}$ )

- Konsekuensi jangka panjang $\left(\mathrm{X}_{5}\right): t_{\text {hitung }} \quad 0,117<t_{\text {kritis }} 1,986$

Kesimpulan: faktor konsekuensi jangka panjang menjadi faktor yang tidak berpengaruh signifikan.

- Affect toward (perasaan individu) $\left(\mathrm{X}_{6}\right): t_{\text {hitung }} 2,194>t_{\text {kritis }} 1,986$

Kesimpulan: faktor affect toward (perasaan individu) berpengaruh signifikan.

\subsubsection{Analisis Koefisien Determinasi $\left(R^{2}\right)$}

Analisis koefisien determinasi $\left(\mathrm{R}^{2}\right)$ digunakan untuk mengetahui seberapa besar pengaruh variabel independent terhadap variabel dependent secara simultan seperti tampak pada tabel 9.

Tabel 9. Analisis Koefisien Determinasi $\left(\mathrm{R}^{2}\right)$

\begin{tabular}{|c|c|c|c|c|}
\hline \multicolumn{5}{|c|}{ Model Summary ${ }^{b}$} \\
\hline Model & & R Square & Adjusted R Square & Std. Error of the Estimate \\
\hline 1 &, $818^{\mathrm{a}}$ & 669 & ,648 & ,40167 \\
\hline Predi & & stant), Aft & $\begin{array}{l}\text { ct toward(X6), Sos } \\
\text { si(X3), Kompleksi }\end{array}$ & $\begin{array}{l}\text { l(x1), Kesesuaian tugas }(\mathrm{X} \\
\text { s(X4), Konsekuensi jang }\end{array}$ \\
\hline
\end{tabular}

Data pada Model Summary pada Adjusted R Square adalah 0,648. Artinya variabelvariabel independent yang digunakan mampu menjelaskan sebesar 64,8\% atas variabel dependent. Prosentase 64,8\% termasuk kategori kuat. Sedangkan sisanya 35,2\% dipengaruhi oleh variabel independent lain yang tidak masuk dalam penelitian ini.

\subsubsection{Uji Asumsi}

\subsubsection{Uji Normalitas}

Uji normalitas dapat dilakukan dengan menggunakan uji Kolmogorov-Smirnov dengan patokan jika angka Kolmogorov-Smirnov $Z>0,05$ maka semua data pada variabel yang diteliti tersebut terdistribusi normal seperti tampak dalam tabel 10. 
Tabel 10. Uji Normalitas

One-Sample Kolmogorov-Smirnov Test

\begin{tabular}{|c|c|c|c|c|c|c|c|c|}
\hline & & $\begin{array}{l}\text { Sosial } \\
(\mathrm{x} 1)\end{array}$ & $\begin{array}{l}\text { Kesesuaian } \\
\text { tugas } \\
\text { (X2) }\end{array}$ & $\begin{array}{l}\text { Kondisi yang } \\
\text { memfasilitasi } \\
\text { (X3) }\end{array}$ & $\begin{array}{c}\text { Kompleksitas } \\
\text { (X4) }\end{array}$ & $\begin{array}{c}\text { Konsekuensi } \\
\text { jangka } \\
\text { panjang } \\
\text { (X5) }\end{array}$ & $\begin{array}{c}\text { Affect } \\
\text { toward } \\
\text { (X6) }\end{array}$ & $\begin{array}{l}\text { Penggunaan } \\
\text { IT dalam } \\
\text { tugas profesi } \\
\text { guru }\end{array}$ \\
\hline \multicolumn{2}{|l|}{$\mathrm{N}$} & 100 & 100 & 100 & 100 & 100 & 100 & 100 \\
\hline \multirow{2}{*}{$\begin{array}{l}\text { Normal } \\
\text { Parameters }{ }^{\mathrm{a}, \mathrm{b}}\end{array}$} & Mean & 3,4900 & 3,3260 & 4,1133 & 2,7855 & 4,4225 & 4,2867 & 3,2314 \\
\hline & $\begin{array}{l}\text { Std. } \\
\text { Deviation }\end{array}$ & ,81849 & ,79425 & ,51076 & 69661 & ,47633 & ,56857 & 67703 \\
\hline \multirow{3}{*}{$\begin{array}{l}\text { Most Extreme } \\
\text { Differences }\end{array}$} & Absolute & 1 & , 117 & , 157 &, 075 & ,212 & ,213 & ,104 \\
\hline & Posit & & &, 143 & 075 &, 212 & ,213 & , 104 \\
\hline & Negative & 5 &,- 117 &,- 157 &,- 059 &,- 187 &,- 195 &,- 092 \\
\hline \multirow{2}{*}{\multicolumn{2}{|c|}{ Kolmogorov-Smirnov Z }} & 1,154 & 1,171 & 1,567 & ,748 & 2,125 & 2,129 & 1,038 \\
\hline & &, 139 &, 129 &, 015 & 631 &, 000 &, 000 & ,232 \\
\hline
\end{tabular}

a. Test distribution is Normal.

b. Calculated from data.

Uji Normalitas dengan Kolmogorov-Smirnov menunjukkan semua variabel mempunyai nilai hitung lebih besar dari 0,05 sehingga data terdistribusi normal.

Pengujian Normal Probability dapat dilihat pada output regresi. Data yang menyebar di sekitar garis diagonal dan mengikuti arah diagonal, dikatakan bahwa model regresi memenuhi asumsi normalitas seperti tampak dalam gambar 4.

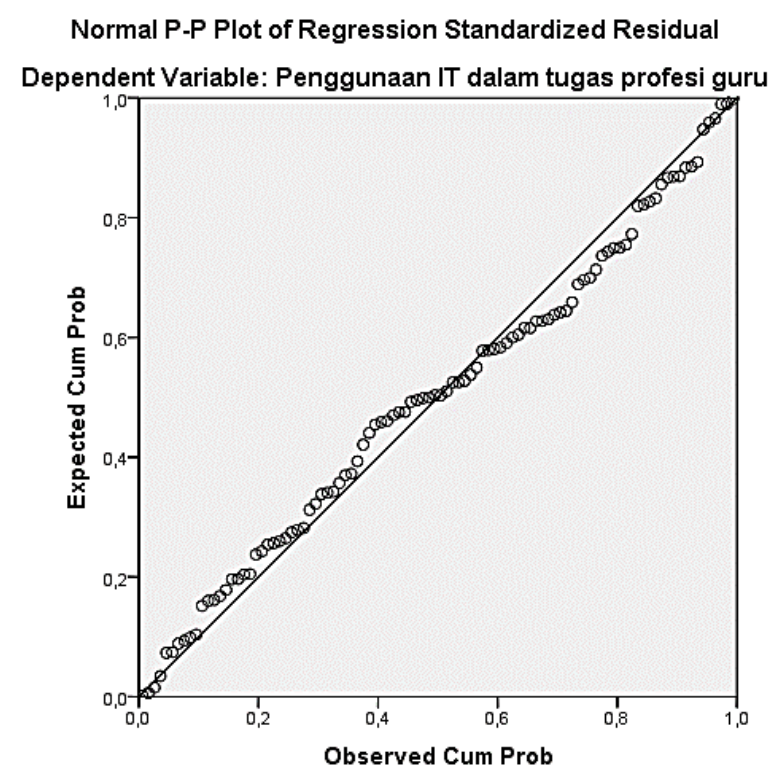

Gambar 4. Uji Normalitas

\subsubsection{Uji Multikolinieritas}

Multikolinieritas adalah keadaan dimana antara dua variabel independen atau lebih pada model regresi terjadi hubungan linier yang sempurna atau mendekati sempurna. Model regresi yang baik mensyaratkan tidak ada masalah multikolinearitas. Jika Tolerance $>0,1$ dan VIF $<10$, dapat disimpulkan tidak terjadi masalah multikolinearitas seperti tampak dalam tabel 11. 
Tabel 11. Uji Multikolinieritas

Coefficients $^{\mathrm{a}}$

\begin{tabular}{|c|c|c|c|c|c|c|c|c|}
\hline & \multirow{2}{*}{ Model } & \multicolumn{2}{|c|}{$\begin{array}{l}\text { Unstandardized } \\
\text { Coefficients }\end{array}$} & \multirow{2}{*}{$\begin{array}{c}\text { Standardized } \\
\text { Coefficients } \\
\text { Beta }\end{array}$} & \multirow[b]{2}{*}{$\mathrm{t}$} & \multirow[b]{2}{*}{ Sig. } & \multicolumn{2}{|c|}{$\begin{array}{l}\text { Collinearity } \\
\text { Statistics }\end{array}$} \\
\hline & & B & $\begin{array}{l}\text { Std. } \\
\text { Error }\end{array}$ & & & & Tolerance & VIF \\
\hline \multirow{7}{*}{1} & (Constant) & 2,888 &, 588 & & 4,909 & ,000 & & \\
\hline & Sosial(x1) & ,046 &, 052 & ,056 & 895 & ,373 & 913 & 1,095 \\
\hline & Kesesuaian tugas(X2) & ,300 & ,065 & ,352 & 4,628 & ,000 & 614 & 1,628 \\
\hline & $\begin{array}{l}\text { Kondisi yang } \\
\text { memfasilitasi(X3) }\end{array}$ &,- 101 & , 100 &,- 076 & $-1,008$ & ,316 & ,622 & 1,608 \\
\hline & Kompleksitas(X4) &,- 480 & ,074 &,- 494 & $-6,495$ & ,000 & 614 & 1,628 \\
\hline & $\begin{array}{l}\text { Konsekuensi jangka } \\
\text { panjang(X5) }\end{array}$ & ,014 & ,117 & ,010 & ,117 & 907 & ,524 & 1,907 \\
\hline & Affect toward(X6) & ,204 & ,093 & ,172 & 2,194 & ,031 & ,580 & 1,723 \\
\hline
\end{tabular}

a. Dependent Variable: Penggunaan IT dalam tugas profesi guru

Dalam tabel Coefficients, Tolerance dan VIF telah memenuhi standar ketentuan.

\subsubsection{Uji Heteroskedastisitas}

Adalah keadaan dimana terjadinya ketidaksamaan varian dari residual pada model regresi. Untuk menguji ada tidaknya Heteroskedastisitas dapat dilihat pada pola - pola scaterplots regresi. Jika titik - titik yang menyebar dengan pola tidak jelas di atas dan di bawah angka 0 pada sumbu Y, maka tidak terjadi masalah heteroskedastisitas. Dari gambar 6 uji heteroskedastisitas menunjukkan titik - titik menyebar dengan pola tidak jelas di atas dan di bawah angka 0 pada sumbu Y sehingga disimpulkan tidak terjadi masalah heteroskedastisitas seperti tampak dalam gambar 5.

Scatterplot

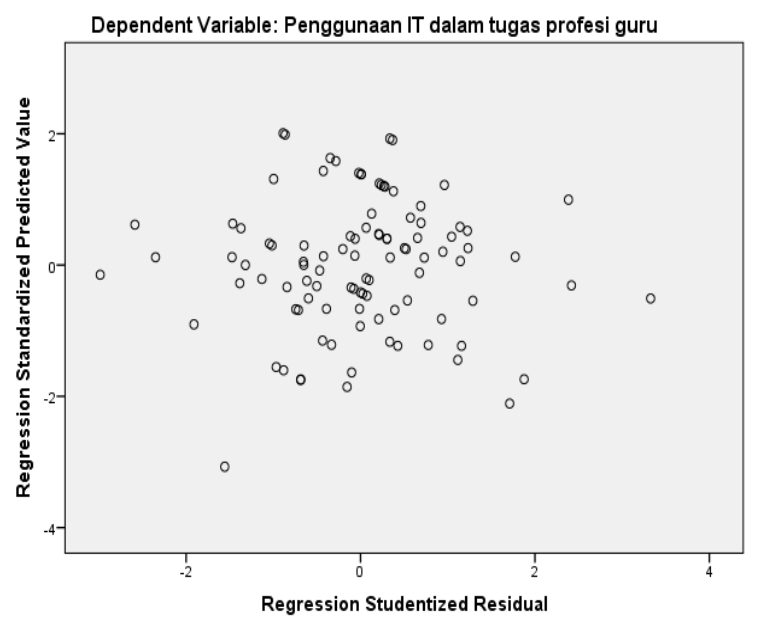

Gambar 5. Uji Heteroskedastisitas

\subsection{Rekomendasi Atas Hasil Penelitian}

Hasil penelitian menunjukkan bahwa faktor kondisi yang memfasilitasi berkontribusi negatif sebesar -0,10 atau menyebabkan penurunan penggunaan IT oleh guru sebesar 3,09\%, artinya bahwa keberadaan fasilitas IT masih perlu ditingkatkan pengadaannya dan dimaksimalkan penggunannya. Tidak maksimalnya penggunaan fasilitas IT dikarenakan masih minimnya kemampuan guru dalam mengoperasikan fasilitas IT tersebut. 
Hasil lainnya menunjukkan bahwa faktor kompleksitas sebuah teknologi informasi berkontribusi negatif sebesar $-0,48$ atau menyebabkan penurunan penggunaan IT oleh guru sebesar $14,86 \%$, artinya bahwa guru masih merasakan bahwa IT adalah sesuatu yang rumit.

Atas dasar hasil penelitian tersebut, maka rekomendasi yang diberikan sebagai solusi untuk meningkatkan penggunaan IT terhadap profesi guru sebagai pendidik yang bertugas mentransfer ilmu adalah berupa pelatihan TIK seperti dalam tabel 12 .

Tabel 11. Rekomendasi Kegiatan Pelatihan TIK

\begin{tabular}{|c|c|c|c|}
\hline No & Nama Pelatihan & Software/aplikasi & Jenis Kegiatan \\
\hline 1 & $\begin{array}{l}\text { Pembuatan } \\
\text { Presentasi Materi } \\
\text { Ajar }\end{array}$ & Ms. Power Point & $\begin{array}{l}\text { 1. Membuat materi pembelajaran dengan Ms. Power } \\
\text { Point } \\
\text { 2. Menginstalasi dan mengoperasikan Laptop } \\
\text { dengan LCD Proyektor }\end{array}$ \\
\hline 2 & $\begin{array}{l}\text { Publikasi Materi Ajar } \\
\text { Online }\end{array}$ & $\begin{array}{l}\text { Email, } \\
\text { Facebook, Ziddu }\end{array}$ & $\begin{array}{l}\text { 1. Membuat akun Email dengan Gmail atau Yahoo } \\
\text { 2. Membuka dan menutup Email } \\
\text { 3. Mengirim berita melalui Email } \\
\text { 4. Mengirim email dengan lampiran file } \\
\text { 5. Membuat akun facebook group mata pelajaran di } \\
\text { sekolah } \\
\text { 6. Mengirim status dengan lampiran file/upload file } \\
\text { 7. Menyimpan data di internet (Cloud Storage) }\end{array}$ \\
\hline 3 & Jelajah Internet & $\begin{array}{l}\text { Mozila Firefox, } \\
\text { Google Chrome }\end{array}$ & $\begin{array}{l}\text { 1. Jelajah internet untuk mencari file - file yang bisa } \\
\text { di download } \\
\text { 2. Jelajah internet untuk mencari artikel/berita yang } \\
\text { akan di copy - paste. }\end{array}$ \\
\hline 4 & Pencarian Web & Google, Yahoo & 1. Update data pada aplikasi online kependidikan \\
\hline
\end{tabular}

\section{KESIMPULAN}

Dari penelitian yang telah dilakukan terhadap guru di Kab. Kebumen setelah dianalisis dengan regresi linier berganda didapatkan sebuah kesimpulan bahwa dari keenam faktor yaitu sosial, kesesuaian tugas, kondisi yang memfasilitasi, kompeksitas, konsekuensi jangka panjang dan affect toward (perasaan individu) ternyata mempengaruhi guru dalam menggunakan IT dalam tugas profesinya sebesar $64,8 \%$

Faktor sosial, kesesuaian tugas, konsekuensi jangka panjang dan affect toward berpengaruh positif terhadap penggunaan IT oleh guru. Faktor kondisi yang memfasilitasi dan kompleksitas berpengaruh negatif terhadap faktor penggunaan IT oleh guru. Agar menjadi positif maka diperlukan optimalisasi pemanfaatan IT yang telah tersedia dan menurunkan faktor kompleksitas. Kompleksitas akan menurun apabila seorang guru telah mampu menjalankan aplikasi - aplikasi atau software yang diperlukan dalam menjalankan profesinya.

Hasil penelitian ini menyimpulkan bahwa pengaruh penggunaan IT terhadap profesi guru baik ketika mentransfer ilmu kepada peserta didik maupun ketika guru melakukan upaya pengembangan dirinya menuju guru yang profesional, belum berjalan maksimal. Hal ini karena masih kurangnya kompetensi guru dibidang IT. Atas dasar hal tersebut, diakhir penelitian ini disusun sebuah rekomendasi tentang kegiatan pelatihan TIK bagi guru, yang diharapkan dengan pelatihan tersebut mampu meningkatkan kompetensi guru dibidang IT. Adapun pelatihan yang direkomendasikan meliputi pelatihan pembuatan presentasi materi ajar, publikasi materi ajar secara online, jalajah internet dan pencarian web. 


\section{SARAN}

Pada penelitian selanjutnya dapat digunakan variabel independen selain dari keenam variabel yang telah digunakan pada penelitian ini, atau dengan metode yang lain seperti UTAUT atau TAM. Atau dengan menggunakan tools AMOS

Materi pelatihan sebagai bahan rekomendasi yang telah disusun masih dapat dikembangkan lagi menggunakan aplikasi lain yang relevan misalnya untuk presentasi dengan Macromedia Flash 8, penyimpanan file dengan 4shared, slideshare atau lainnya.

\section{DAFTAR PUSTAKA}

[1] Lembaran Negara Republik Indonesia, 2003, Undang- undang Republik Indonesia Nomor 20 Tahun 2003 Tentang Sistem Pendidikan Nasional, Sekretaris Negara Republik Indonesia, Jakarta, 8 Juli 2003.

[2] Menteri Pendidikan Nasional Republik Indonesia, 2007, Peraturan Menteri Pendidikan Nasional Nomor 41 tentang Standar Proses untuk Satuan Pendidikan Dasar dan Menengah, Jakarta, 23 November 2007.

[3] Utomo, B. S., Widodo, 2012, Model Peningkatan Kinerja Inovatif dalam Konteks Teknologi Informasi, Jurnal Dinamika Manajemen, Vol 3, No. 2, Hal 133-140.

[4] Rusman., Kurniawan, D., Riyana, C., 2011, Pembelajaran Berbasis Teknologi Informasi dan Komunikasi: Mengembangkan Profesionalitas Guru, Rajawali Pers, Jakarta.

[5] Rachmawaty, A., 2014, Pengaruh Pemanfaatan Teknologi Informasi Terhadap Kinerja Guru pada SMP Negeri 43 Bandung, TEMATIK-Jurnal Teknologi Informasi Vol.1, Politeknik LP3I, Bandung, 1 Juni 2014.

[6] Winarko, B., Mahadewi, L., 2013, Tinjauan Beberapa Model Teori Dasar Adopsi Teknologi Baru, Media Bisnis, ISSN: 2085-3106, Vol 5, No 1, hal 21-31.

[7] Sundayana, R., 2014, Statistika Penelitian Pendidikan, Alfabeta, Bandung.

[8] Setiawan, N., 2007, Penentuan Ukuran Sampel Memakai Rumus Slovin danTabel KrejcieMorgan: Telaah Konsep dan Aplikasinya, Diskusi Ilmiah Jurusan Sosial Ekonomi Fakultas Peternakan Unpad, Bandung, 22 November 2007.

[9] Priyatno, D., 2013, Analisis Korelasi, Regresi, dan Multivariate dengan SPSS, Gava Media, Yogyakarta. 